\title{
INFLUENCE OF THE UNDERGROUND MINING WASTE ON THE ENVIRONMENTAL TAILINGS AND WASTEWATER CHARACTERIZATION
}

\author{
Marija Stojmenović ${ }^{1}$, Snežana Pašalić ${ }^{1}$, Milan Kragović
}

Received: Sptember 15, 2017

Accepted: December 3, 2017

\begin{abstract}
In presented paper influence of the underground mining waste on the environmental was investigated. From that point tailings and wastewater characterization was performed on samples taken from lead and zinc mine Grot, Serbia. In order to obtain experiments necessary for characterization, representative samples were taken from three different parts of the tailings: outlet pipe of the flotation facility (JOF), hydrocyclone overflow (JHC) and crest of dam (JKB). Characterization of the tailing samples include: thermal (differential thermal analysis and thermogravimetric analysis (DTA/TGA) and infrared analysis (FTIR), determination of the chemical composition and content of the heavy metals and qualitative roentgen analysis (XRPD). Also, wastewater samples have been taken from the tailings and concentrations of heavy metals in the taken samples were determined by using inductively coupled plasma mass spectrometry (ICPMS).
\end{abstract}

Keywords: tailings; wastewater; lead and zinc mine Grot; characterization; heavy metals;

\section{INTRODUCTION}

The materials which remain after mining or technological processing of ore represents an industrial waste. In general, industrial waste, due to its characteristics, may be hazardous or non-hazardous. The waste which is obtained due to mining activities, and is disposed on the landfill is named tailing (Stevanović et al., 2003). Unfortunately, tailings are often located in environments which have cultural, historical and very often touristic potential. Also, the tailings may have an influence on the agricultural production, contamine water (ground and underground sources) as well as air and consequently tailings may have an influence on human and animal health. Tailings, especially those obtained from mines which are active for a long time are very often located near water sources, so very easily the water sources may be contaminated and polluted.

\footnotetext{
${ }^{1}$ University of Belgrade, Institute for nuclear science, Vinča 
Mine Grot is located on the southeast slope of the mountain Besna kobila, in southeastern part of Serbia in the municipality of Bosilegrad. This part of the Republic, administrativly is named a basin of South Morava, while the locals named it Krajište. Near tailings of the mine is located small town Kriva Feja.

The environment of the tailings and mine Grot is characterized with very beautiful nature with a high potential for turism and there are located numerious protected natural areas: in the southeastern part of tailings is a monument of nature-black pine tree in Crnoštica, eastern from the tailings is Jarešnik-Special Nature Reserve and northern Vlasina range which is in the protection process (Institute for Nature Conservation of Serbia, 2005).

From aspect important for mining, it is good to know that the first geological data of this area is found in the Boue-a (1836) and Toula-e (1883) researchings. These researchers found that in the north of the Kriva Feja (Mountain-Crna Trava-Trn) was located phyllite, quartzite and micas.

Vankov (1900) noted that the oldest shales lie in the field Crnooka and registered presence of the granite in Topli Dol, Donja Lisina, Bosilegrad, Ljubatska Reka, Dukat, Jarešnik and Bucalovu. The same researcher found young volcanic rocks and tuffs in Karamanica area and Besna kobila, and first described presenceof the mineral raw materials $(\mathrm{Pb}$, and $\mathrm{Zn})$ in Blagodat in Talamine and Resn; magnetite in Božica and gold in the neogen near Bosilegrad. With these studies started first organized mining activities in the wider region of Blagodat.

Cvijić (1911) described a lake terraces between the Vranjska Banja and Suvojnica, and Dinić (1923) sediments in Pčinja and Surdulica. Petković (1937) indicated Pb-Zn occurrences in Karamanici. Ilić $(1939,1940,1950,1954)$ explored the petrochemical composition of Surdulica massif, volcanic companion, crystalline schists and surroundings and the occurrence of mineral deposits within the massif. According to the same author, the pluton is imprinted between the Cretaceous and Tertiary.

Djordjevic (1962) investigated the occurrence of magnetite in crystalline schists in wider area of Vlasina.

Pavlović (1957) in its mineralogical-petrological studies noted that massive of Surdulica embedded in two phases, where the first was given the "gneiss-granite" under the influence of simultaneous granitization,weld and alkalization of gneiss, while the second crushing gneiss-granite which led to the formation of granite with hornblende.

The first commercial research and organized exploitation of these areas started in 1903, when the Italian Mining Company "Societe Comercial d'Oriente "conducts research and exploitation of the outcrops in „Djavolja vodenica“ and Kula. These activities lasted until the beginning of II World War. In this period around 10,000f of lead and zinc ore was expolated (Mijatović, 2006). 
Exploration and exploitation in 1914 were suspended because of the effects of war. After this, at the Krasnodolska into Crna reka remained deposited mine tailings and flotation treated material (Đokić, 2007). Mining activities concerning mineral field Blagodat were suspended between two World War period.

In time period from 1958.-1972. the ore field Blagodat was investigated by geological, geochemical and geophysical methods. The result of researchings leds the opening of the mine. At the point where it is located today, in 1963. the facility in which it is carried flotation $\mathrm{Pb}-\mathrm{Zn}$ ore was built. Reserves of $\mathrm{Pb}$ and $\mathrm{Zn}$ ore in deposit were certified in 1969. Amount of mineral reserves of $A+B+C 1$ categories are 4,766.241 t with medium content of $4.16 \%$ of $\mathrm{Pb}$ and $4.24 \% \mathrm{Zn}$.

Between 1984 and 1991. started production of detailed geological maps in ratio1: 25,000, and continuation of the detailed geological plan 1: 1,000 of Blagodat ore deposit.

Tailing obtained due to mining company Grot activities is located at the highest altitude in Serbia. The highest part of the top dam is $1,178 \mathrm{~m}$, medium height of thee central plateau is $1,172 \mathrm{~m}$ and altitude of the central collector is 1,099 $\mathrm{m}$ (Đokić, 2007). In the tailings is located about 5.5 million tons floated tailing materials, mainly in the state of biological vacuum.

The main task of this paper was to determine whether the tailings of the flotation facility of the lead and zinc mine Grot, Serbia potentially dangerous for the nature and environmental. For that purpose, on samples taken from tailings, characterisation was performed and include: thermal (differential thermal analysis and thermogravimetric analysis -DTA/TGA) and infrared analysis (FTIR), determination of the chemical composition and content of the heavy metals and qualitative roentgen analysis (XRPD). Also, wastewater samples have been taken from the tailings and concentrations of heavy metals in the taken samples were determined.

\section{EXPERIMENTAL}

In order to obtain experiments necessary for characterization expreriments, representative samples were taken from three different parts of the tailings of the mine Grot: outlet pipe of the flotation facility (JOF), hydrocyclone overflow (JHC) and crest of dam (JKB).

The chemical composition of the tailing was determined by the classical chemical analysis of the alumosilicates (Voinovitch, 1966). The concentrations of investigated heavy metals were determined by atomic absorption spectrometry (AAS) by using “Analytic Jena Spekol 300" instrument. 
Thermal analysis, (DTA/TGA) was performed on a Netzsch STA 409 EP instrument. Samples were heated from 25 to $1000^{\circ} \mathrm{C}$ in an air atmosphere with a heating rate of $10^{\circ} \mathrm{C} / \mathrm{min}$.

Structural properties of the samples were determined by infrared spectroscopy. The Fourier transform infrared (FTIR) spectroscopic analyses of tailings samples were performed using a Thermo Scientific "Nicolet iS50" spectrometer with diamond attenuated total reflectance (ATR) smart accessory at spectrum resolution of $2 \mathrm{~cm}^{-1}$ and 64 scans over a range of $4000-400 \mathrm{~cm}^{-1}$. After recording the spectra, two corrections were performed: automatic correction of the base line and atmospheric suppression.

The mineralogical analysis of samples, JOF, JKB and JPH was performed by X-ray Powder Diffraction (XRPD) analysis. All samples were characterized at room temperature by using Ultima IV Rigaku diffractometer, equipped with $\mathrm{Cu} \mathrm{K} \alpha 1,2$ radiation, using a generator voltage $(40.0 \mathrm{kV})$ and current $(40.0 \mathrm{~mA})$, without monochromator. The range of $2 \theta 10^{\circ}-90^{\circ}$ was used for all powders in a continuous scan mode with a scanning step size of $0.02^{\circ}$ and at a scan rate of $2^{\circ} \mathrm{min}^{-1}$. Data for structural refinement were taken in the $2 \theta$ range $10^{\circ}-90^{\circ}$, with a scanning step size of $0.02^{\circ}$ and at a scan rate of $0.5^{\circ} \mathrm{min}^{-1}$.

Wastewater samples have been taken from the outlet pipe of the flotation facility (OF) and hydrocyclone overflow (PHC) in accordance with standard procedure (SRPS ISO 5667-10:2007, Water quality. Taking of sample. Part 10: Guidance on waste waters sampling). Collected samples were kept in the capped container and left at room temperature in order to separate liquid from solid phase. After few days, liquid phase was decanted and filtered through qualitative filter paper in order to remove large particles and impurities. Then, concentrations of heavy metals in the wastewaters were determined by using inductively coupled plasma mass spectrometry.

\section{RESULTS AND DISCUSSION}

\subsection{Chemical analysis}

The results obtained by classical chemical analysis of the samples taken from different areas of the tailings - flotation facility (JOF), hydrocyclone overflow (JHC) and crest of dam (JKB) are given in Tables 1 and 2. 
Table 1 Chemical composition of the tailings of the flotation facility of the mine Grot

\begin{tabular}{lccc}
\hline & JHC & JKB & JOF \\
\hline $\mathrm{SiO}_{2}, \%$ & $48.61(22.68 \% \mathrm{Si})$ & $40.09(18.71 \% \mathrm{Si})$ & $53.62(25.02 \% \mathrm{Si})$ \\
$\mathrm{Al}_{2} \mathrm{O}_{3}, \%$ & $12.94(6.85 \% \mathrm{Al})$ & $8.68(4.60 \% \mathrm{Al})$ & $10.52(5.57 \% \mathrm{Al})$ \\
$\mathrm{CaO}, \%$ & $9.33(6.66 \% \mathrm{Ca})$ & $9.08(6.48 \% \mathrm{Ca})$ & $8.73(6.24 \% \mathrm{Ca})$ \\
$\mathrm{MgO}, \%$ & $2.74(1.65 \% \mathrm{Mg})$ & $1.86(1.12 \% \mathrm{Mg})$ & $2.15(1,30 \% \mathrm{Mg})$ \\
$\mathrm{Fe}_{2} \mathrm{O}_{3}, \%$ & $11.8(8.26 \% \mathrm{Fe})$ & $16.46(11.52 \% \mathrm{Fe})$ & $10.42(7.29 \% \mathrm{Fe})$ \\
$\mathrm{Na}_{2} \mathrm{O}, \%$ & $0.98(0.73 \% \mathrm{Na})$ & $0.75(0.56 \% \mathrm{Na})$ & $0.97(0.72 \% \mathrm{Na})$ \\
$\mathrm{K}_{2} \mathrm{O}, \%$ & $2.10(1.74 \% \mathrm{~K})$ & $1.46(1.21 \% \mathrm{~K})$ & $1.94(1.61 \% \mathrm{~K})$ \\
$\mathrm{TiO}_{2}, \%$ & $1.01(0.61 \% \mathrm{Ti})$ & $1.01(0.61 \% \mathrm{Ti})$ & $0.84(0.50 \% \mathrm{Ti})$ \\
$\mathrm{Mn}_{2} \%$ & 1.14 & 1.05 & 1.17 \\
$\mathrm{~S}, \%$ & 1.52 & 8.07 & 2.14 \\
Loss on ignition, \% & 7.23 & 10.67 & 6.91 \\
\hline
\end{tabular}

Table 2 The content of heavy metals in tailings of the flotation facility of the mine Grot

\begin{tabular}{lcccc}
\hline & JHC & JKB & JOF & Ref. value \\
\hline $\mathrm{Cd}, \mathrm{mg} / \mathrm{kg}$ & 18 & 14 & 12 & 1 \\
$\mathrm{~Pb}, \mathrm{mg} / \mathrm{kg}$ & 2800 & 6700 & 2100 & 10 \\
$\mathrm{Cr}, \mathrm{mg} / \mathrm{kg}$ & 94 & 61 & 74 & 10 \\
$\mathrm{Ni}, \mathrm{mg} / \mathrm{kg}$ & 60 & 70 & 55 & 10 \\
$\mathrm{Cu}, \mathrm{mg} / \mathrm{kg}$ & 120 & 73 & 55 & 50 \\
$\mathrm{Zn}, \mathrm{mg} / \mathrm{kg}$ & 2700 & 2200 & 2000 & - \\
$\mathrm{Sb}, \mathrm{mg} / \mathrm{kg}$ & 100 & 70 & 55 & 0.7 \\
$\mathrm{Ba}, \mathrm{mg} / \mathrm{kg}$ & $<$ D.L. & <D.L. & $<$ D.L. & 100 \\
\hline
\end{tabular}

Results presented in Table 1 showed that all samples mainly consist silica $(\sim 23, \sim 19$ and $\sim 25 \%$ for JHC, JKB, JOF, respectively), while the content of alumina was about 7, 6 and $5 \%$ for JHC, JKB, JOF, respectively. In addition to these elements, all three samples contain relatively high amounts of calcium ( $~ 9 \%)$, while the content of magnesium, potassium and sodium, as well as manganese and titanium was much lower. According to results presented in Table 1, the main difference between these three samples was in the content of iron which was very high and was about 8, 12 and $7 \%$ for JHC, JKB and JOF, respectively. Also, in all three samples sulphur was detected. The content of sulphur in JKB $(8.07 \%)$ was about fourth time higher in comparison with JPH and JOF (1.52 and $2.14 \%$, respectively), indicating presence of higher amounts of sulphide minerals in the JKB.

By using chemical analysis of tailings materials it was also determined the content of heavy metals in investigated samples and results are presented in Table 2. If the content of heavy metals is compared, it may be concluded that the content of iron in all three investigated samples was much higher than concentration of other heavy metals. Even 
more, the amount of iron for all three samples was much higher (>80 \%) than total amount of all other heavy metals (14-18\%) in the tailings (Figure 1).
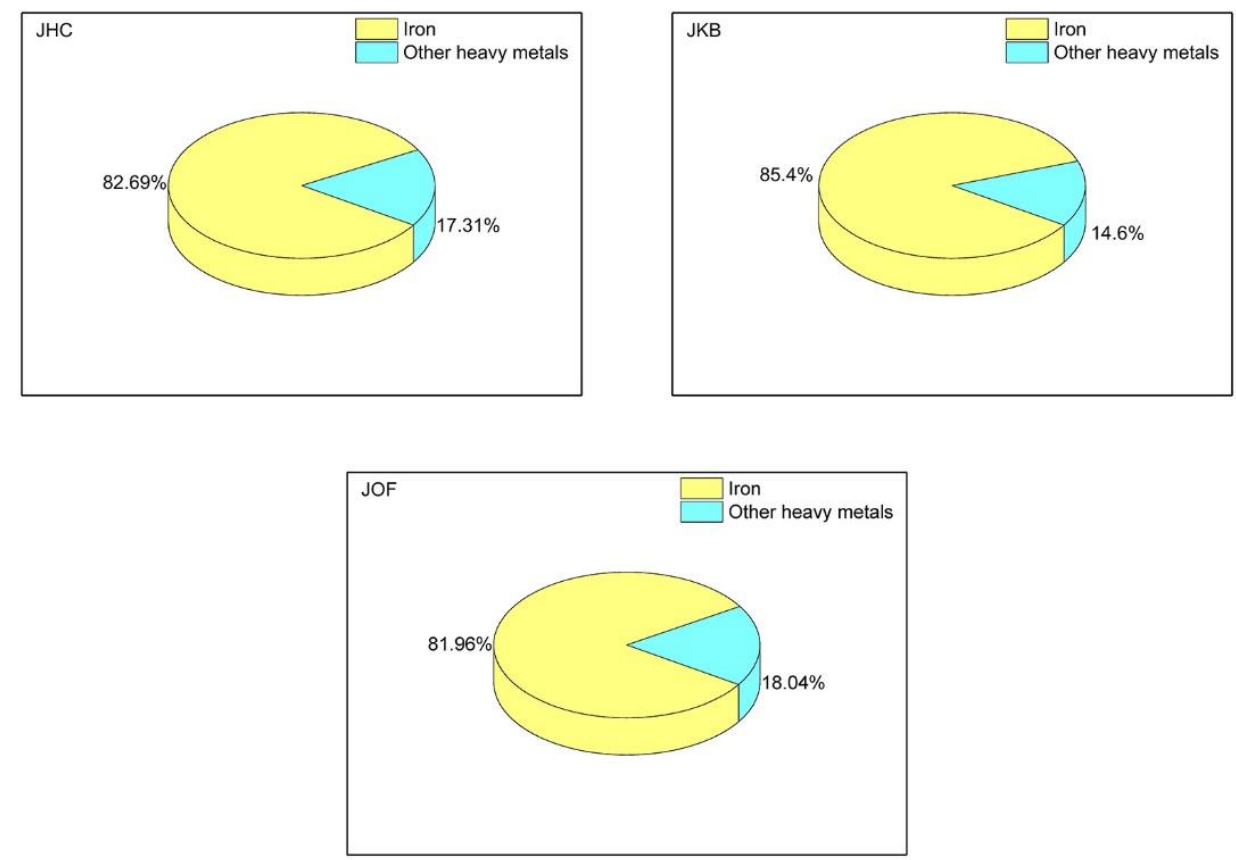

Figure 1 Ratio between the content of iron and other heavy metals in samples taken from three different parts of tailings from flotation facility of lead and zinc mine Grot, Serbia.

Also, as it can be seen from Table 2, the concentrations of all heavy metals $(\mathrm{Cd}, \mathrm{Pb}, \mathrm{Cr}$, $\mathrm{Ni}, \mathrm{Cu}$ and $\mathrm{Sb}$ ) except $\mathrm{Ba}$ were much higher than referent values prescribed by the laws of Republic of Serbia ("Uverenje o utvrđivanju karaktera otpada, 2007”, Table 2). Consequently, according to the law of the Republic of Serbia ("Sluzbeni glasnik Republic of Serbia, 12/95”), investigated tailings samples may be classified as a dangerous waste.

\subsection{Thermal analysis}

The results obtained of thermal treatment of the samples taken from different areas of tailings are given in Figure 2 and Table 3.

As it can be seen from Figure 2 and Table 3 there is no huge difference in thermal properties between JOF and JPH, while slightly different behaviour was obtained for JKB. The TGA curves of all three samples showed non-continual trends in investigated temperature range. Very small weight losses $(0.07 \%$ for JOF, $0.21 \%$ for JKB and 0.64 $\%$ for $\mathrm{JPH})$ obtained in the first temperature area $\left(25-400^{\circ} \mathrm{C}\right)$ are mainly due to moisture 
losses. However, since the amount of the released moisture was very small, the characteristic DTA peaks were not observed, and DTA curves were practically unchanged. In second temperature region $\left(400-650^{\circ} \mathrm{C}\right)$, one exothermic peak with maximum at $478^{\circ} \mathrm{C}$ was obtained by differential thermal analyses of the JOF and JPH, while weight losses of 1.39 (JOF) and $2.17 \%$ (JPH) were obtained by TG analyses. On the other side, two exothermic peaks with much higher intensities in comparison with JOF and JPH were obtained for JKB. The peaks maximums were at 493 and $535^{\circ} \mathrm{C}$, while in this temperature region, mass loss for the sample JKB was $3.92 \%$.

Sulphide lead and zinc ores are always associated with other waste minerals known as 'gangue', usually calcite $\left(\mathrm{CaCO}_{3}\right)$, pyrite $\left(\mathrm{FeS}_{2}\right)$ or barytes $\left(\mathrm{BaSO}_{4}\right)$. Our results of chemical analysis showed $\sim 8, \sim 12$ and $\sim 7 \%$ of iron in JPH, JKB and JOF, respectively, as well as $\sim 2 \%$ of sulphur for JPH and JOF and about $8 \%$ for JKB. Since ratio between contents of iron and sulphur is not like in pyrite $(\mathrm{Fe} / \mathrm{S}=0.88)$, and for all three samples the content of iron was much higher than amount necessary for pyrite which may be obtained from registered amount of sulphur in samples, these results suggest that beside presence in form of pyrite iron is also present in some of other forms, probably in form of oxide, chalcopyrite etc... Also, this is additionally supported with the fact that the sulphur is beside pyrite partly in the form of other minerals with $\mathrm{Pb}, \mathrm{Zn}, \mathrm{Ni}, \mathrm{Cu}$, etc. which may be presented in lead and zinc mine tailings.

In DTA curves (Figure 2) of all three samples, due to much smaller amounts of other heavy metals in comparison with iron (Figure 1), peaks characteristic for their minerals $(\mathrm{PbS}, \mathrm{ZnS}, \mathrm{NiS}, \mathrm{CuS})$ were not detected. Accordingly, regarding to shape and position of DTA peaks in second temperature interval, it may be concluded that DTA peaks with maximums at $478^{\circ} \mathrm{C}$ for JOF and JPH are due to presence of pyrite and its decomposition. On the other side, two exothermic peaks with maximums at 493 and $535^{\circ} \mathrm{C}$ obtained in DTA curve of the sample JKB, may be an indication that beside pyrite (peak at $493^{\circ} \mathrm{C}$ ) iron was also presented in form of oxide $\left(\mathrm{Fe}_{2} \mathrm{O}_{3}\right)$ (peak at $\left.535^{\circ} \mathrm{C}\right)$ (MacKenyie, 1970).

In the third temperature range $\left(650-1000^{\circ} \mathrm{C}\right)$ for all three samples an endothermic peaks with minimums at 796,812 and $775^{\circ} \mathrm{C}$ were obtained at DTA curves of JOF, JKB and $\mathrm{JPH}$, respectively. These peaks are characteristic for oxidation of carbonates and in all samples probably come from siderite $\left(\mathrm{FeCO}_{3}\right)$ and calcite $\left(\mathrm{CaCO}_{3}\right)$, which also were detected by XRPD analyses of samples (Figure 4). The decomposition of carbonates was followed with weight loss of 5.66, 6.41 and $6.03 \%$ for JOF, JKB and JPH (Table 3).

Table 3 Mass loss for investigated samples in different temperature regions

\begin{tabular}{lcccc}
\hline & \multicolumn{4}{c}{ Temperature, ${ }^{\circ} \mathrm{C}$} \\
\cline { 2 - 5 } & $25-400$ & $400-650$ & $650-1000$ & $25-1000$ \\
\hline JOF & 0.07 & 1.39 & 5.66 & 7.12 \\
JKB & 0.21 & 3.92 & 6.41 & 10.54 \\
JPH & 0.64 & 2.17 & 6.03 & 8.84 \\
\hline
\end{tabular}



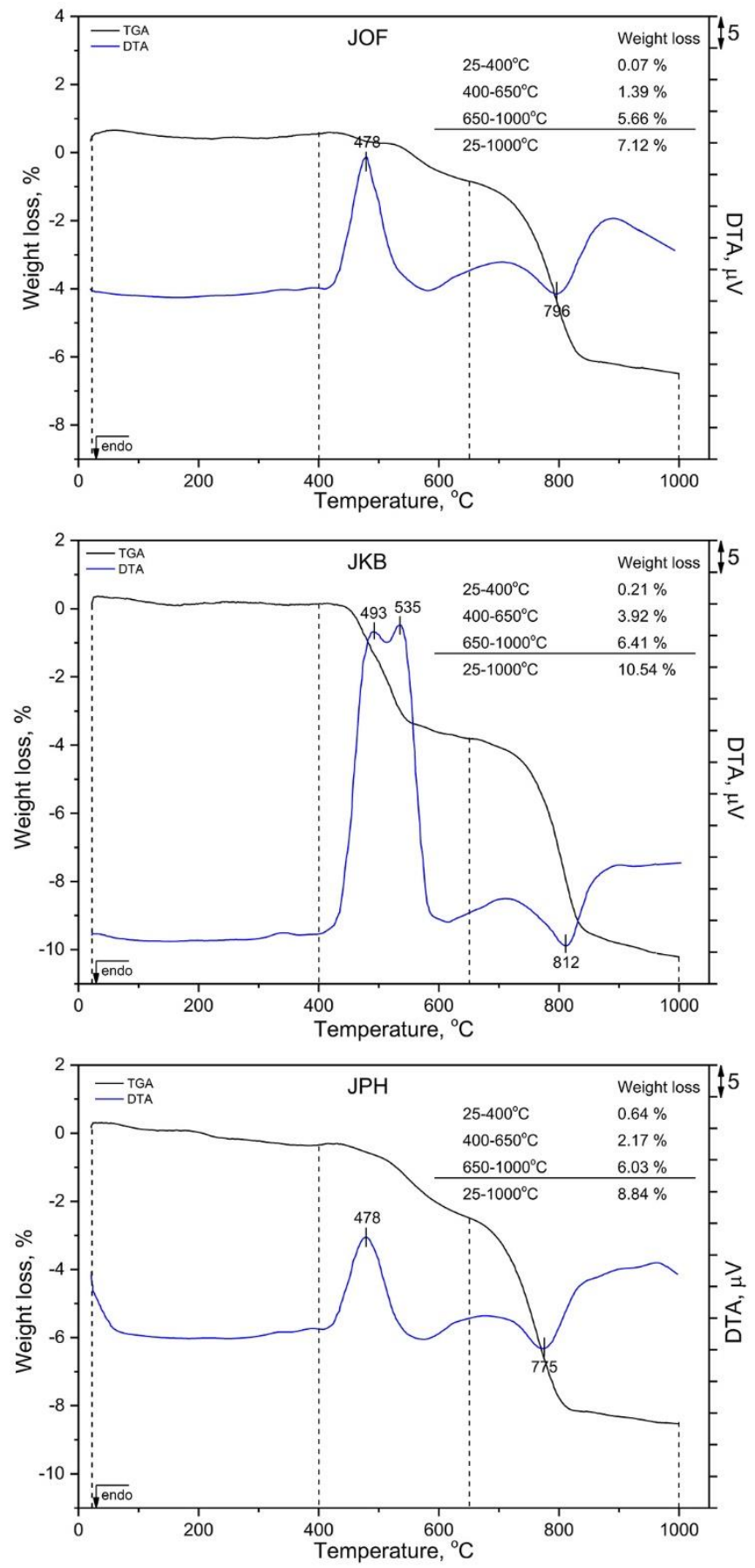

Figure 2 Thermal analysis of the JOF, JKB and JPH 


\subsection{Infrared spectroscopic analysis (FTIR)}

Structural properties of the samples were determined by infrared spectroscopy and obtained results are presented in Figure 3.

As it may be seen from Figure 3, infrared spectra of all three samples are very similar each other and identical spectral bands appear in the spectra without significant changes in positions. That is in agreement with results of XRPD analysis of samples where almost the same and identical qualitative mineral composition of samples was observed. The spectrum of each sample is a resulting spectrum of all minerals which are included in the composition of a given sample. Thus, due to partial or complete overlapping of spectral bands, it was not possible to identify every individual mineral and determine exact composition of every sample. However, in all spectra it was possible to identify spectral bands and to assign their wave numbers. The band centred at $\sim 1420 \mathrm{~cm}^{-1}$ is due to the asymmetric internal stretching mode $v_{3}$ of the $\mathrm{CO}_{3}$ group which is characteristically broad for many carbonates. The measured value represents a composite of the transverse and longitudinal components of this vibration. The band at $\sim 870 \mathrm{~cm}^{-1}$ arise from the out-ofplane bending mode, $v_{2}$ of the $\mathrm{CO}_{3}$. Existing of these two spectral bands confirmed presence of the calcite or siderite in all three samples (Samanta et al., 2016; Dubrawski and Channon, 1989).

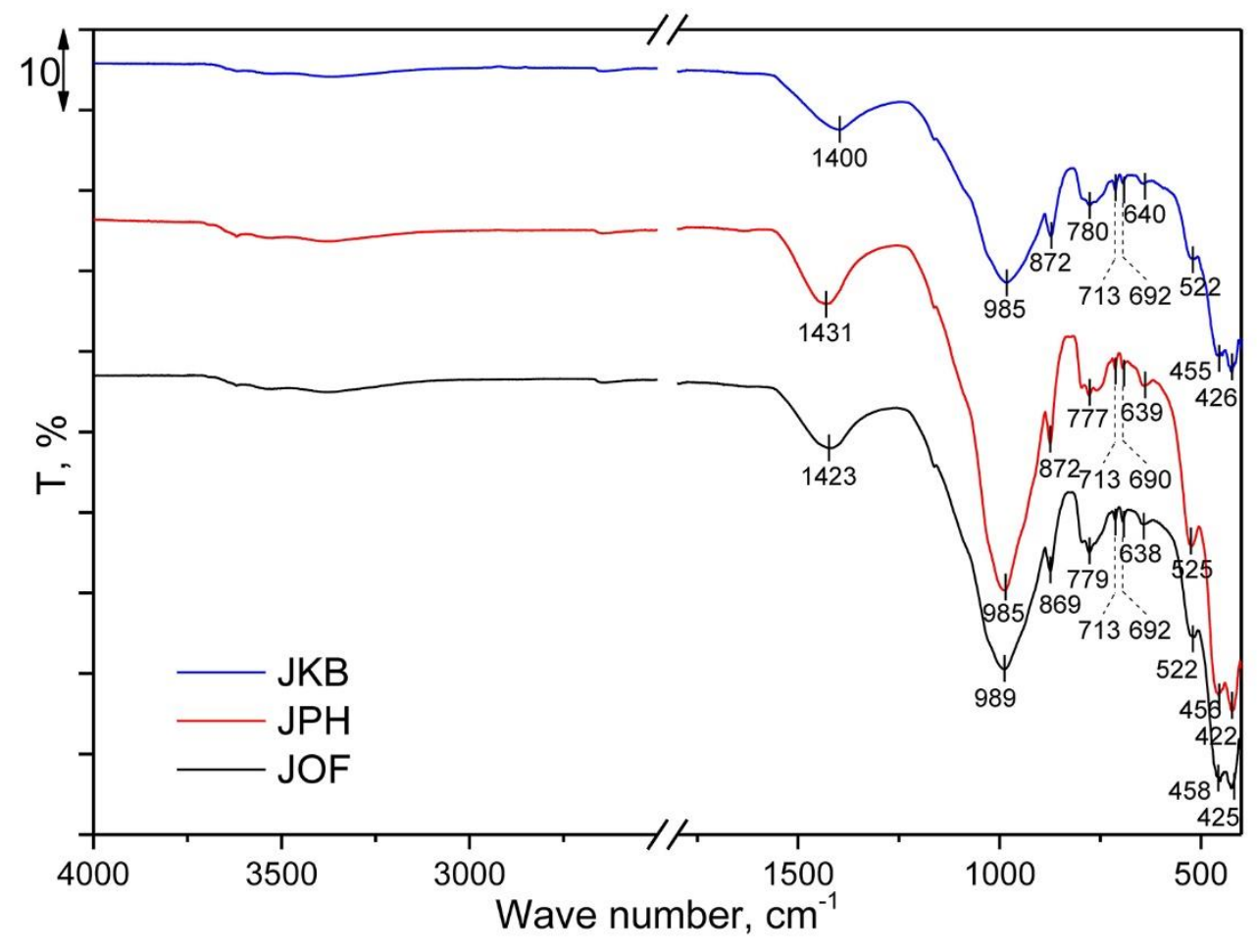

Figure 3 FTIR spectra of the JOF, JKB and JPH. 
Spectral bands characteristic for iron oxide are not visible in spectra of JOF, JKB and $\mathrm{JHC}$, probably due to overlapping them with bands originating from other groups. On the other side, two spectral bands of very low intensities at 713 and $~ 692 \mathrm{~cm}^{-1}$ which are characteristic for pyrite suggest presence of the $\mathrm{FeS}_{2}$ in all three samples (RRUFF Project, 2017). Other spectral bands are characteristic for alumosilicate minerals (Marković et al., 2017) The strongest vibration band at $\sim 985 \mathrm{~cm}^{-1}$ is assigned to asymmetric $\mathrm{Si}-\mathrm{O}-\mathrm{Si}$ and $\mathrm{Si}-\mathrm{O}-\mathrm{Al}$ stretching vibrations. In the region from 400 to $\sim 640$ $\mathrm{cm}^{-1}$ are bands that are assigned to $\mathrm{Si}-\mathrm{O}$ and $\mathrm{Al}-\mathrm{O}$ bending vibration modes. Band at $775 \mathrm{~cm}^{-1}$ is due to symmetric Si-O-Si and probably originated from quartz (Kocak, 2013).

\subsection{Roendgen analysis}

The mineralogical analysis of samples, JOF, JKB and JPH was performed by X-ray Powder Diffraction (XRPD) analysis. The obtained results are given in Figure 4 a-c.

As it can be seen from Figure 4 there are no huge difference between roentgen diffractograms of JOF, JKB and JPH. According to the obtained x-ray diffraction patterns of polycrystalline samples it was obtained that all three samples contain minerals quartz, clinochlore, calcite, phlogopite, siderite, iron oxide and anorthoclase.

Identification of the present phases was made based on the FullProf computer program and JCPDS Cards (Card No. 00-033-1161 for quartz, 00-029-0701 for clinochlore, 1010962 for calcite, 01-089-4212 for phlogopite, 00-002-0837 for siderite, 00-054-0489 for iron oxide, and 00-009-0478 for anorthoclase).

Finally, the microscopic analysis of investigated samples was performed. For that purpose, a polarisation microscope Carl Zeiss-Jena JENAPOL with measuring equipment and computer software Carl Zeiss AxioVision SE64 Rel. 4.9, module Multiphase and camera Axiocam 105 color was used. The mineralogical composition of the samples was determined by immerse method (as immersion xylene was used) with qualitative identification of present minerals. Lens zoom was 10x (Obtained results are not shown).

According to obtained results it was concluded that all three samples contain minerals: quartz, chlorite, minerals form carbonate group-calcite, feldspar group of minerals orthoclase and clays group of minerals. The most abundant mineral in the samples is quartz, chlorite then carbonates and feldspar (K-feldspar, plagioclase and), while micas are side minerals. Also, in all samples, it was pronounced crystallinity of main phases. Results also showed that particle size was the highest for sample JKB, and lowest for the JPH. 

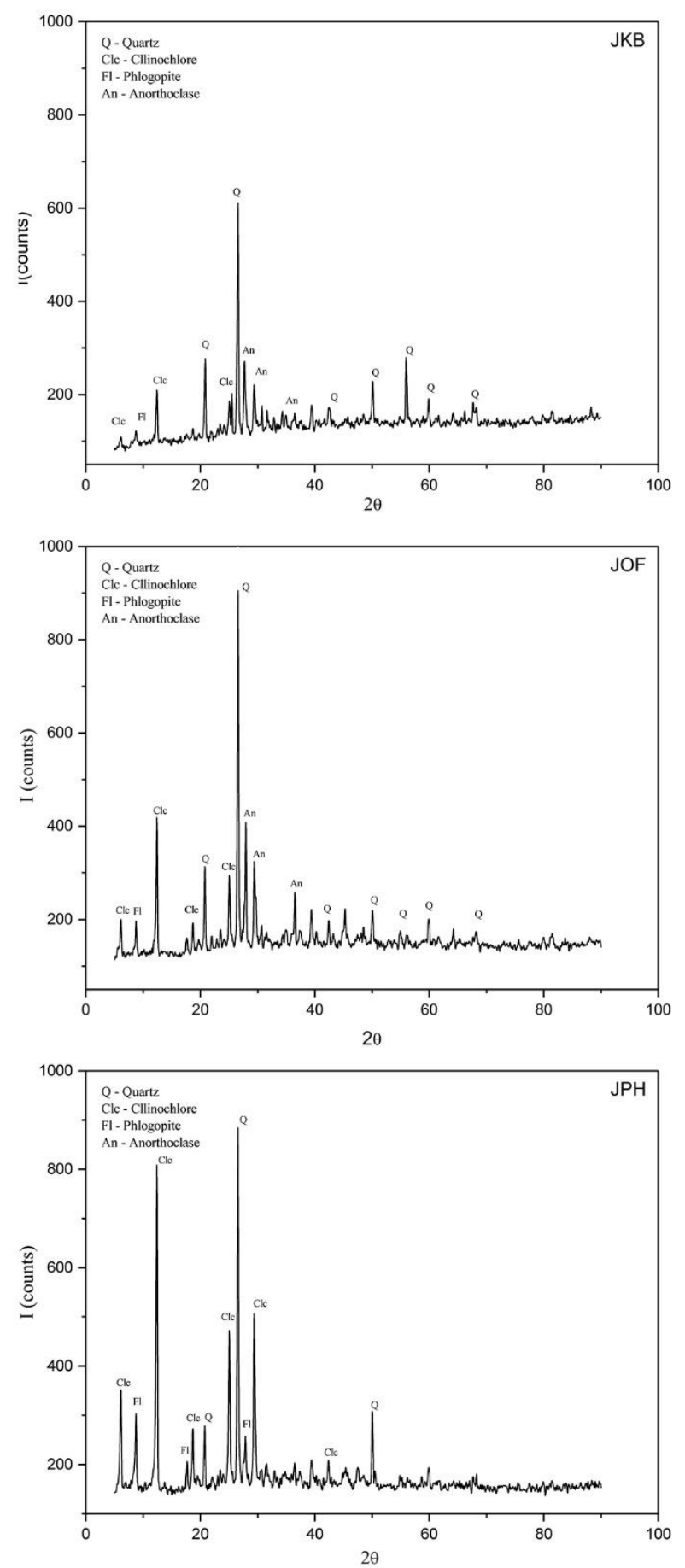

Figure 4 XRPD diffraction patterns of JKB, JOF and JPH 


\subsection{Tailing wastewaters}

The above results clearly demonstrated that tailings from flotation facility of lead and zinc mine Grot, Serbia according to its composition may be classified as a dangerous waste. This is also supported by the fact that until now, on the tailings is deposited more than 5.5 million tons of tailing materials. Since the complete isolation of the tailings from the environment is not possible, its influence on the nature, including humans, animals and plants may be hazardous and with a serious consequences for health. In the environmental, hazardous constituents of the tailings could enter in different ways: 1) by scattering-through air, whereby by inhalation or secondary contamination of the soil or surface waters or plants may result in serious health problems for humans or animals; 2) by penetration into the deeper layers of soil and groundwater contamination and 3) through wastewaters which leave tailings.

In this paper a special attention was paid to wastewaters which leave tailings. Namely, wastewaters continuously leave the tailings in the amount of $100-200 \mathrm{~m}^{3} / \mathrm{h}$ depending on the level of production of ore in flotation facility. These wastewaters over streams "Seliški potok", "Soboštica", "Klisurska reka" and "Korbevačka reka" flows into rivers "Južna Morava" and over "Velika Morava" finally flows into "Danube". For that reason it was of interest to investigate quality of water which is produced at tailings. For that purpose, wastewater samples have been taken from the outlet pipe of the flotation facility (OF) and hydrocyclone overflow (PHC) in accordance with standard procedure (SRPS ISO 5667-10:2007, Water quality. Taking of sample. Part 10: Guidance on waste waters sampling). Collected samples were kept in the capped container and left at room temperature in order to separate liquid from solid phase. After few days, liquid phase was decanted and filtered through qualitative filter paper in order to remove large particles and impurities. Then, concentrations of heavy metals in the wastewaters were determined by using inductively coupled plasma mass spectrometry. Results are shown at Table 4.

As may be seen from Table 4 the concentrations of $\mathrm{Zn}, \mathrm{Hg}, \mathrm{Mn}, \mathrm{Pb}, \mathrm{Ni}, \mathrm{Cr}$ are higher, while concentrations of other investigated elements are below maximal allowed amount (MDK) according to listed standards. The concentrations of lead, mercury and manganese were very high and for mercury it was more than 2000 time higher than allowed amount, while for lead and manganese the concentrations were 10 and 40-60 times higher, respectively. The $\mathrm{pH}$ of taken samples was about 7.2 indicating that heavy metals are mainly present in less mobile and dangerous - hydroxide form (REF). However, the $\mathrm{pH}$ downstream from the tailings in rivers is more acidic (in "Južna Morava" $\mathrm{pH}$ is about 6.5), meaning that more dangerous, cationic forms, of heavy metals is present. In contrast to the most of the organic pollutants, heavy metals are difficult to degrade in the nature and are easily accumulated in living organisms, thereby causing various diseases and disorders (Wang et al., 2017). It is known that heavy metals damage the kidney, liver, reproductive system, basic cellular processes, may 
irritate the mucous membranes, leading to hepatic and renal damage, widespread capillary damage, central nervous system or problems with brain functions (Gaetke and Chow, 2003; Larous, 2005; Hao et al., 2015). For that reason it may be concluded that water obtained from this tailings is dangerous and it should be treated from aspect of environmental as well as for human or animal health protection.

Table 4 The content of heavy metals in ppm in wastewaters obtained from tailings

\begin{tabular}{ccccc}
\hline & $\begin{array}{c}\text { PHC (Kragović et al., } \\
2017)\end{array}$ & OF & MDK1 & MDK2 $^{* *}$ \\
\hline $\mathrm{Zn}$ & 0.338 & 0.269 & 0.2 & $0.024-0.8$ \\
$\mathrm{Hg}$ & 2.568 & 1.304 & 0.001 & $0.00001-$ \\
$\mathrm{Mn}$ & 3.069 & 2.568 & 0.1 & 0.0003 \\
$\mathrm{Cd}$ & $<0.045$ & $<0.045$ & 0.005 & - \\
$\mathrm{Fe}$ & 0.075 & 0.179 & 0.3 & $0.0006-$ \\
$\mathrm{Ba}$ & $<0.007$ & $<0.007$ & - & - \\
$\mathrm{Be}$ & $<0.004$ & $<0.004$ & - & - \\
$\mathrm{Cu}$ & $<0.017$ & $<0.017$ & 0.1 & $0.0013-0.075$ \\
$\mathrm{Al}$ & 0.065 & 0.023 & 0.2 & - \\
$\mathrm{Mg}$ & 8.105 & 7.631 & 50 & - \\
$\mathrm{Ca}$ & 98.859 & 117.983 & 200 & - \\
$\mathrm{Si}$ & 3.221 & 3.668 & - & - \\
$\mathrm{Pb}$ & 0.611 & 0.402 & 0.05 & $0.0017-0.075$ \\
$\mathrm{Ni}$ & 0.068 & 0.072 & 0.05 & $0.0021-0.075$ \\
$\mathrm{Cr}$ & 0.093 & 0.169 & 0.1 & $0.0025-0.03$ \\
$\mathrm{Sr}$ & 0.604 & 0.496 & - & - \\
\hline
\end{tabular}

*MDK (maximum allowed amount) according to law of the Republic of Serbia, Regulations for Hazardous Substances in Waters, "Službeni glasnik SRS 31/82" and "Službeni list SRJ $42 / 98 "$ ".

**Target values and soil remediation intervention values and background concentrations soil/sediment and groundwater for metals. Dutch Target and Intervention Values, 2000 (the New Dutch List) 


\section{CONCLUSION}

In presented paper are shown results of tailings and tailing wastewater characterization. Results obtaipresented by clasical chemical analysis showed that the main difference between three investigated samples was in the content of iron which was very high and much higher than content of other constituents, and was about 8, 12 and $7 \%$ for JHC, $\mathrm{JKB}$ and JOF, respectively. Also, in all three samples sulphur was detected. The content of sulphur in JKB $(8.07 \%)$ was about fourth time higher in comparison with JPH and JOF (1.52 and $2.14 \%$, respectively), indicating presence of higher amounts of sulphide minerals in the JKB. Also, the concentrations of heavy metals $\mathrm{Cd}, \mathrm{Pb}, \mathrm{Cr}, \mathrm{Ni}, \mathrm{Cu}$ and $\mathrm{Sb}$ except $\mathrm{Ba}$ were much higher than referent values prescribed by the laws of Republic of Serbia. Consequently, according to the law of the Republic of Serbia investigated tailings samples may be classified as a dangerous waste.

Results of therma analysis indicate presence pyrite in JOF and JPH sample. On the other side, from DTA curve of the sample JKB, it was indicated that beside pyrite (peak at $493^{\circ} \mathrm{C}$ ) iron was also presented in form of oxide $\left(\mathrm{Fe}_{2} \mathrm{O}_{3}\right)$ (peak at $\left.535^{\circ} \mathrm{C}\right)$. Infrared spectra of all three samples are very similar each other and identical spectral bands appear in the spectra without significant changes in positions. Also, presence spectral bands at $\sim 1420$ $\mathrm{cm}^{-1}$ and $\sim 870 \mathrm{~cm}^{-1}$ confirmed presence of the calcite or siderite in all three samples. Results of roendgen analysis showed that there are no huge difference between roentgen diffractograms of JOF, JKB and JPH. According to the obtained x-ray diffraction patterns of polycrystalline samples it was obtained that all three samples contain minerals quartz, clinochlore, calcite, phlogopite, siderite, iron oxide and anorthoclase. Results of determining content of heavy metal cations in the tailings wastewater showed that concentrations of lead, mercury and manganese were very high and for mercury it was more than 2000 time higher than allowed amount, while for lead and manganese the concentrations were 10 and 40-60 times higher in comparison with maximal allowed amounts.

Finally, it may be concluded that tailings as well as tailings wastewater from mine Grot are dangerous for environment and may have a negative impact on human, animals and plant health. From that point, additional activities are needed.

\section{ACKNOWLEDGEMENT}

We are thankful to the Ministry of Education, Science and Technological Development of the Republic of Serbia, which has been financing projects, TR34013, III 45012 a part of which is presented in this paper. 


\section{REFERENCES}

STEVANOVIĆ B. ET AL. (2003) Enciklopedija životna sredina i održivi razvoj-knjiga tačnih odgovora. Srpsko Sarajevo: Zavod za udžbenike i nastavna sredstva.

BOÙE A. (1836) Esqusse geologique de la Tuquie d'la d' Europe. Geološki anali Balkanskog poluostrva, 3 .

TOULA F. (1883) Geologishe untersuchungen in westlichen theile des Balkan und Angrezenden Gebieten. 10. Von Pirot nach Sofia aut die Vitosa uber Pernik nach Trn und uber Stol nach Pirot. Sitzungsberichte Akad. Wiss. Bd, 88, pp. 1279-1346.

VANKOV L. (1900) Geologičeski izučvania na pogranična mestnos na zapad od TrnKjustendil. In: Sbornik nar. umotvorenia, knj. XVI, deo III. Sofia.

CVIJIĆ J. (1911) Osnove za geografiju i geologiju Makedonije i Stare Srbije. Beograd: Srpska kraljevska akademija.

DINIĆ J. (1925) Rasprostranjenje pčinjskog ugljenog bazena. In: Zapisnici Srpskog geološkog društva za 1923, pp. 26-27.

PETKOVIĆ K. (1936) Pojave olovnih ruda u okolini sela Luka i Karamanica severno od Krive Palanke. Glasnik Skopskog naučnog društva, 5, pp. 1-8.

ILIĆ M. (1939) Rezultati prethodnih petrografskih istraživanja na listu Vranje. In: Godišnjak Geološkog instituta za 1938, Beograd. Beograd, pp. 75-78.

ILIĆ M. (1940) Međusobni odnosi eruptiva okoline Surdulice. In: Zapisnici SGD za 1939. godinu, Beograd. Beograd, pp. 13-15.

ILIĆ M. (1950) Metalogeneza Surduličkog eruptivnog masiva. In: Zapisnici SGD za 1948. godinu, Beograd. Beograd, pp. 3-7.

ILIĆ M. (1954) Magmatske stene okoline Surdulice i njihov odnos prema molibdenskim ležištima ove oblasti. In: Vesnik Zavoda za geološka i geofizička istraživanja, knjiga XI, Beograd. Beograd, pp. 127-197.

ĐORĐEVIĆ Ž. (1962) Pojave gvozdene rude u oblasti Vlasine. Beograd: Fond Geozavoda.

PAVLOVIĆ P. (1957) Problema metamorfičeskih doordovikskih porod vnizoviah i Ljubatskoj reki nedaleko od goroda Bosiljgrada. In: VIII kongres KBGA, tom II, Beograd. Beograd.

MIJATOVIĆ P. (2006) Elaborat o rezervama olova i cinka rudnika GrotVranje (Đavolja vodenica 2, Vučkovo ležište, Jezerište). Beograd: Geološki institut Srbije. 
ĐOKIĆ B. V. and JOVANOVIĆ M. (2007) Jalovišta Blagodata-potreba za uspostavljanjem iskrenih odnosa prirode i čoveka. In: Zbornik radova, II simpozijum „Reciklažne tehnologije $i$ održivi razvoj" sa međunarodnim učešćem, Tehnički fakultet u Boru Univerziteta $u$ Beogradu. Sokobanja: Katedra za mineralne i reciklažne tehnologije, pp. 68-75.

VOINOVITCH I., DEBRAD-GUEDON J. and LOUVRIER J (1966) The Analysis of Silicates. Jerusalem: Israel Program for Scientific Translations.

MACKENYIE R.C. (1970) Differential thermal analysis. London: Academic Press INC.

SAMANTA A. ET AL. (2016) Syntesis of mixed calcite-calcium oxide nanojasmine flowers. Ceramics International, 42, pp. 2339-2348.

DUBRAWSKI J.V. and CHANNON A-L. (1989) Examination of the siderite-magnesite mineral series by Fourier transform infrared spectroscopy. Amerian Mineralogist, 74, pp. 187-190.

RRUFF Project (2017) Pyrite R050190. [Online] RRUFF Project. Available from: http://rruff.info/Pyrite/R050190/25.4.2017 [Accessed 5/8/17].

MARKOVIĆ M. et al. (2017) Adsorption of mycotoxin zearalenone by clinoptilolite and phillipsite zeolites treated with cetylpyridinium surfactant. Colloids and Surfaces B: Biointerfaces, 151, pp. 324-332.

KOCAK Y., TASCI E. and KAYA U. (2013) The effect of using natural zeolite on the properties and hydration characteristics of blended cements. Constr Build Mater, 47, pp.720727.

WANG J. et al. (2017) Adsorption characteristics of novel ceramsite for heavy metal removal from stormwater runoff. Chinese Journal of chermical Engineering.

GAETKE L.M. and CHOW C.K. (2003) Copper toxicity, oxidative stress, and antioxidant nutrients. Toxicology, 189, pp. 147-163.

LAROUS S., MENIAI A.H. and LEHOCINE M.B. (2005) Experimental study of the removal of copper from aqueous solutions by adsorption using sawdust. Desalination, 185, pp. 483-490.

HAO W. et al. (2015) Screen-printed gold electrode with gold nanoparticles modification for simultaneous electrochemical determination of lead and copper. Sensors Actuators B Chem., 209, pp. 336-342.

KRAGOVIĆ M. et al. (2017) Removal of heavy metals from aqueous solutions by using natural and Fe(III)-modified zeolite-alginate composites. In: 6th International Symposium of mining and environmental protection, Vrdnik, Serbia, June 21 - 24. 2017. pp. 164-169. 